FOLIA PRAEHISTORICA POSNANIENSIA T. XIII/XIV - 2005

INSTYTUT PRAHISTORIL. UAM POZNAN' - ISBN 83-7177-388-9 ISSN 0239-8524

\title{
O KAZIMIERZU SIUCHNIŃSKIM - WSPOMNIENIE PO LATACH
}

\author{
ABOUT KAZIMIERZ SIUCHNIŃSKI - RECOLLECTIONS YEARS AFTER
}

\author{
Stanislaw Kukawka \\ Instytut Archeologii, Uniwersytet Mikołaja Kopernika \\ ul. Szosa Bydgoska 44/48, 87-100 Toruń. Poland
}

Doprawdy niełatwo napisać oficjalne wspomnienie o osobie bardzo bliskiej. Trudno bowiem pisać obiektywnie, bez emocji i uczuć. Kazimierz Siuchniński był moim Nauczycielem, Mistrzem i Przyjacielem. Takim pozostaje w mojej pamięci. Żadne słowa nie są w stanie wyrazić w pełni moich myśli i wspomnień o Nim. Zatem wystarczyłoby może, gdybym napisał, że Go pamiętam, i że po dwudziestu pięciu latach ciągle mi Go brakuje.

Chciałbym jednak zaprezentować kilka zaledwie osobistych wspomnień i refleksji. Zdaję sobie sprawę, że nie oddają one w pełni moich uczuć. Nie stanowią też dostatecznej choćby charakterystyki Mistrza. U tych, którzy Go znali, ten krótki tekst przywoła może własne wspomnienia. Tym, którzy Go nie znali, może przybliży nieco tę wyjątkową osobowość.

Moja przygoda z archeologią neolitu rozpoczęła się u boku doktora, a później docenta Kazimierza Siuchnińskiego. Na tych studentów, którzy mieli z Nim bliższy kontakt, wykraczający poza określone programem studiów godziny dydaktyczne i egzaminy, wywarł niemały wpływ. Wyjątkowa i pogodna osobowość, pasja badawcza, dydaktyczna i wychowawcza były Jego największymi atutami w kształtowaniu młodych pokoleń archeologów.

Kazimierz Siuchniński był życzliwym i troskliwym opiekunem mojego (naszego) roku. Pierwszy raz zobaczyłem Go w trakcie egzaminów wstępnych na studia. Jako przyszły opiekun roku przeprowadzał z kandydatami rozmowę kwalifikacyjną. Stremowany (bezpośrednio po ustnych egzaminach $\mathrm{z}$ geografii i historii) odpytywany byłem o motywacje wyboru kierunku studiów, o znajomość archeologii i archeologów, o przeczytaną literaturę i o moje „dokonania naukowe”. Deprymował mnie uczony konkludujący moje starania, by wypaść jak najlepiej, ironicznymi złośliwostkami. Bynajmniej Go wtedy nie polubiłem. Burzyliśmy się jako studenci pierwszego roku, gdy nasz Opie- 
kun odbywał z nami indywidualne rozmowy, aby jak najwięcej dowiedzieć się o naszej sytuacji rodzinnej i osobistej. Dla studentów, dorosłych przecież i odpowiedzialnych ludzi, taka dociekliwość była nie do przyjęcia. Szybko jednak okazało się, że w sytuacjach trudnych można było zawsze liczyć na Jego pomoc. Doświadczali jej koledzy, ja także.

Niekonwencjonalne były wykłady Kazimierza Siuchnińskiego. Wydawały się one nie mieć logicznego układu, w odbiorze studentów były chaotyczne. Kolejne poruszane problemy, dość luźno z sobą powiązane, zmieniały się jak w kalejdoskopie. Nikt nie nadążał za tokiem myślowym Wykładowcy. W żadnym razie nie była to prosta prezentacja źródeł czy wiedzy już ustalonej. Widocznie Nauczyciel uważał, że te informacje znajdziemy sami w literaturze. Wykłady dotyczyły najczęściej kwestii trudnych, niekiedy spornych i w owych latach w środowisku naukowym dyskutowanych. Muszę przyznać, że niektóre $\mathrm{z}$ nich zrozumiałem dopiero w trakcie realizacji pracy magisterskiej, niektóre jeszcze później. Bywało, że w trakcie wykładu padały pytania, na które na ogół nikt nie potrafil odpowiedzieć. Interesujący bywał też przebieg egzaminów; „sto pytań", często bardzo skojarzeniowych, niekiedy wykraczających poza zakres przedmiotu (ponieważ nie da się omawiać neolitu bez wiedzy o mezolicie, bo poszczególne zjawiska kulturowe nie znają granic państwowych). Niekiedy dramaturgii spektaklu dopelniała z nagła rzucona przed blade oblicze studenta stara niemiecka książka, przestrzelona w trakcie dzialań wojennych i jakże cenna, skoro wewnątrz nadal znajdują się ilustracje (oczywiście z dziurą po kuli), co do których student powinien się wypowiedzieć. Warto też wspomnieć o organizowanych przez naszego Opiekuna wycieczkach

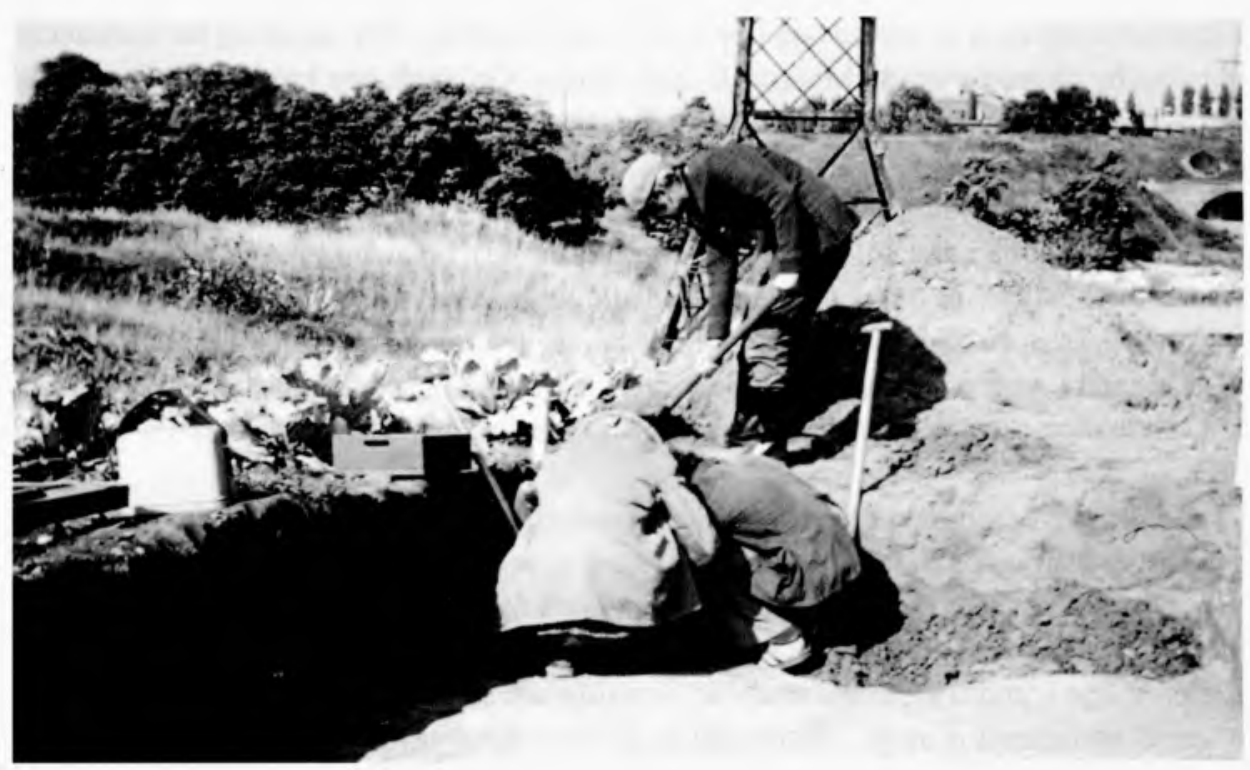

Badania w Szczecinie-Ustowie. Zapaleni do archeologii studenci eksploruja obiekt neolityczny. Doktor Kazimierz Siuchniński odsypuje hałdę, kontrolując poczynania studentów (1975 r.) 
dydaktycznych. Sami, pod Jego czujnym okiem, wymyślaliśmy trasy, organizowaliśmy przejazdy i rezerwowaliśmy noclegi, przygotowywaliśmy też informacje o zwiedzanych obiektach. Wycieczki - obok wymiaru naukowo-dydaktycznego - powiązane były z turystyką i nie tylko. Były to wspaniałe chwile „konsolidacji” naszego roku, w których nasz Opiekun aktywnie - choć z umiarem - uczestniczył, umiejętnie czuwając nad naszym bezpieczeństwem

W latach 1975-1979 miałem zaszczyt uczestniczyć we wszystkich kierowanych przez Kazimierza Siuchnińskiego terenowych badaniach wykopaliskowych i powierzchniowych. Zaangażowany byłem w realizację pasjonującej Go problematyki badawczej związanej z neolitem i początkami epoki brązu, do której powrócił w ostatnich latach swego życia. Już jako student pierwszego roku, we wrześniu 1975 r., wraz z kilkoma kolegami brałem udział w weryfikacyjnych badaniach wykopaliskowych w Szczecinie-Ustowie i w Śmiardowie Krajeńskim. Praca fizycznie była ciężka, a uzupełnianie dokumentacji kończyliśmy niekiedy około północy. Codziennym jednak rytuałem była wspólna kolacja trwająca niekiedy dwie-trzy godziny. To chyba tam poznaliśmy prawdziwe oblicze naszego Szefa. Był świetnym gawędziarzem i dyskutantem, a tematyka rozmów byla przeróżna: o archeologii, o archeologach, o życiu, o nas studentach, o Nim. Kto znał Pana Doktora, ten znał też te Jego talenty. On sam w czasie takiego kolejnego kolacyjnego posiedzenia zwierzył się, że zna tylko jedną osobę „lepszą” od siebie, która opowiada nawet wówczas, gdy wszyscy już śpią i wtedy, gdy wszyscy jeszcze śpią. Była to opinia o Tadeuszu Wiślańskim.

W późniejszych latach brałem udział w badaniach na Pojezierzu Krajeńskim, którym mój Mistrz zainteresowany był szczególnie. Były to badania wykopaliskowe w Kruszkach i w Dworzakowie oraz kilka akcji rozpoznania powierzchniowego. Powierzano mi tam bardziej odpowiedzialne zadania, z których starałem się wywiązywać jak najlepiej. Nie obywało się jednak bez wpadek i pouczających, ojcowskich reprymend. Tam także uczestniczyłem we wspaniałych rozmowach, bywało, że byłem tylko słuchaczem monologów. Pasja badawcza przybierała niekiedy wymiar humorystyczny. Podam jeden przykład. W Kruszkach rozentuzjazmowany Kazimierz Siuchniński, pierwszego dnia badan, uroczo podskakując na stanowisku, zawołał do mnie: „panie Staszku! tu są te groby!'”. Niestety nie było ich, ale to Szefa nie zrażało. Wierzył, że będą kolejne sezony badawcze, nowe stanowiska i nowe odkrycia.

Bywało, że na badania powierzchniowe nie było żadnych funduszy. Nigdy jednak nie miałem problemów, by na wyjazd z K. Siuchnińskim skompletować ekipę kolegów. Jeden z wyjazdów pamiętam szczególnie. Nocowaliśmy bowiem w szkole milicyjnej w Pile, a w teren woziła nas milicyjna Nysa z kierowcą milicjantem. W drugiej połowie lat siedemdziesiątych było to dla nas studentów przeżycie dość zabawne. Zabawne były też reakcje zdezorientowanej ludności wiejskiej, zwłaszcza obywateli trochę „zmęczonych" przydługim siedzeniem $\mathrm{w}$ barze.

Wspominając wyjazdy terenowe należy też nadmienić o stroju doc. dr. hab. Kazimierza Siuchnińskiego. Zawsze ta sama sfatygowana nieco kurtka ortalionowa, a na głowie ni to beret, ni to czapka $\mathrm{z}$ daszkiem nasuniętym na czoło. Wyglądał tak niepozornie. 


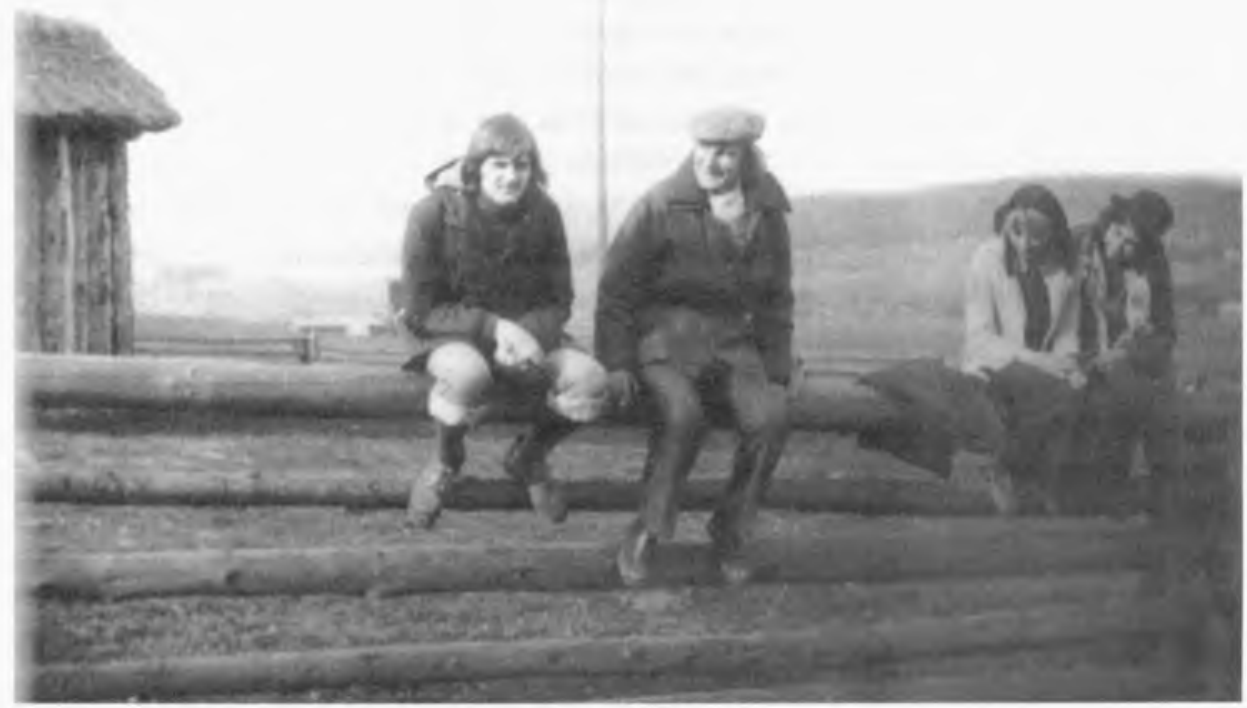

Doktor Kazimierz Siuchniński na wycieczce dydaktycznej w swoim ulubionym stroju terenowym (1975 r.)

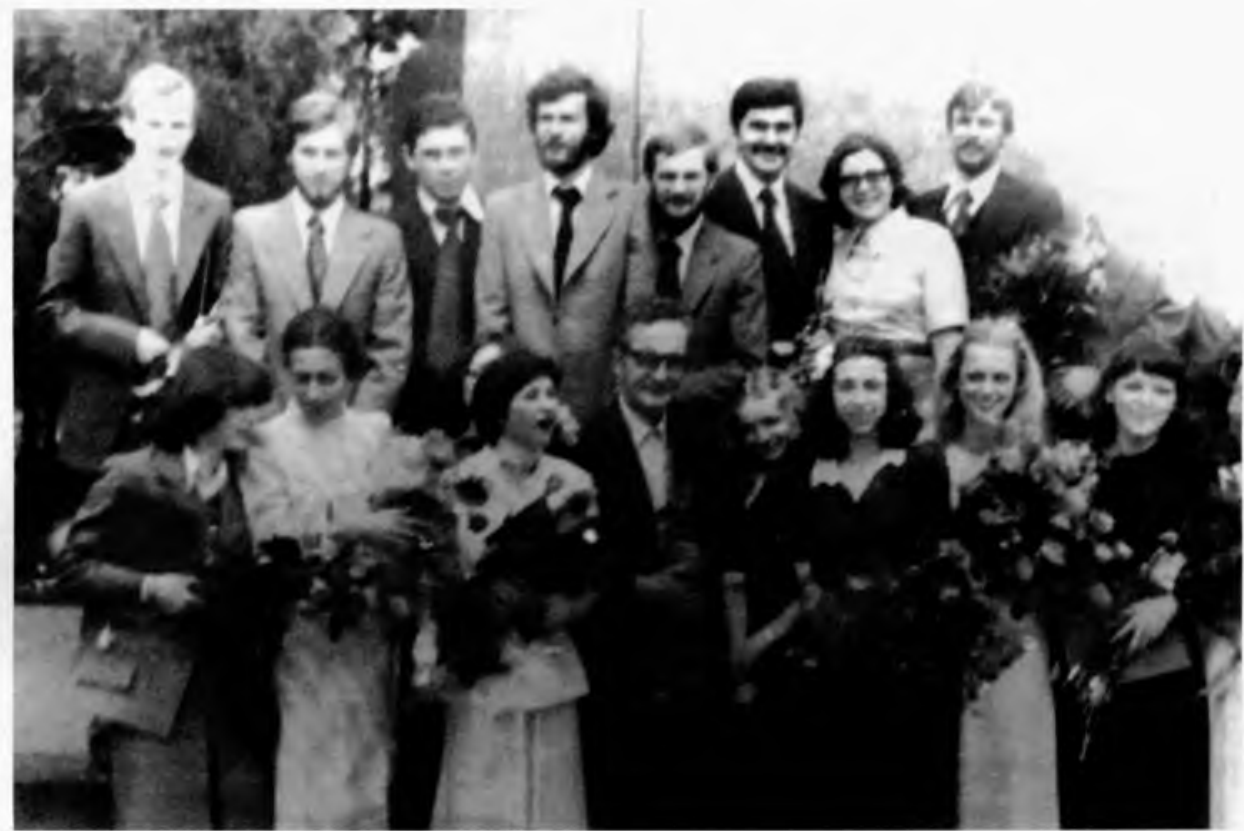

Doc. dr hab. Kazimierz Siuchniński z grupa swoich podopiecznych tuż po absolutorium. Zdjęcie wykonano pod pomnikiem Adama Mickiewicza w Poznaniu. W grupie znajduje się też dr Dobrochna Jankowska (1979 r.) 
Zdarzały się sytuacje, gdy ciekawi informacji rolnicy pytali nas studentów, kim jest ten człowiek chodzący z nami po polu. Zabawnie było obserwować ich zdumienie, gdy dowiadywali się, że to nasz Szef, docent na uniwersytecie, i że to On nas tu przywiózł.

Pod mistrzowsko dydaktycznym kierunkiem doc. dr. hab. Kazimierza Siuchnińskiego realizowałem pracę magisterską, której podstawą źródłową były zbiory ceramiki neolitycznej pochodzące $z$ Jego badań. Był promotorem szczególnym. Zawsze miał dla mnie czas, bardzo dużo czasu. Nigdy nie krytykował moich niezliczonych i rewolucyjnych wręcz pomysłów. Przeciwnie, zachęcal do podejmowania coraz to nowych prób rozwijania metody analitycznej. Mobilizowało to do poszukiwań i eksperymentów. Rzecz jasna, realizacja sporej części pomysłów poznawczo do niczego nie prowadziła, o czym Mistrz, jak sądzę, wiedział, ale mi nie powiedział. Patrząc na te nieudane i udane próby po latach doceniam Jego cierpliwość i swoiste wpuszczanie w maliny. Doświadczenia z okresu pisania pracy magisterskiej okazały się bowiem w przyszłości bezcenne; sądzę, że mój Promotor i o tym wiedział. Czytając gotowe części pracy, rzadko tekst poprawiał. Najczęściej na marginesie ołówkiem zapisywał różne uwagi krytyczne dotyczące kwestii merytorycznych, stylistycznych i gramatycznych. W skrajnym przypadku, bodaj w ,dopieszczonym” już (jak mi się zdawało) wstępie, napisał: „tekst młotkowy”. Sam dochodziłem, w czym tkwi owa młotkowość.

Wiele troski okazał mi doc. Siuchniński jako opiekun, gdy okazało się, że powołany zostałem do odbycia służby wojskowej i to $w$ terminie kolidującym $z$ konkursem na stanowisko asystenta w Instytucie Archeologii i Etnografii Uniwersytetu Mikołaja Kopernika w Toruniu. Start w konkursie był dla mnie życiową szansa. Podejmowane przez mego Szefa próby - choć nieudane - by odroczyć mój pobór były zdumiewające i wskazują na ogromną determinację, by mi pomóc. W końcu otrzymałem upragniony etat i zaraz potem przez rok „broniłem ojczyzny”. W swoim archiwum jak relikwię przechowuję wzruszający list doc. Siuchnińskiego, skierowany do mnie, do jednostki wojskowej. Nie dość, że trafiłem tam w kilka dni po ślubie, to jeszcze mój szczery zapał do archeologii musiał zostać na rok wyhamowany. Były to wystarczające powody, by mieć pretensje do życia i podły nastrój. Pozwolę sobie zacytować krótki fragment tego listu:

To wszystko trzeba po prostu przeżyć i przezw y c i ̨̇ż ć, choć próba to niełatwa, ale pierwsza z poważnych prób życiowych.

Najpierw więc trzeba ją mieć za sobą, a potem, zamiast zastanawiać się nad własnymi brakami, wziąć się do ich likwidacji. Gra się toczy o niemałą stawkę, a najłatwiej przekreślić wszystko, co się już osiągnęło. Musi Pan zresztą trochę powalczyć, bo zwiększyła się liczba bliskich o tych mam nadzieję - najbliższych! A Ci snują różne plany, licząc na Pana niezawodność. Nieskromnie zaliczam i siebie do tego grona.

Ostatnie zacytowane zdanie zaszczycało mnie wówczas i zaszczyca nadal. W wojsku też, dzięki życzliwej pomocy Pana Docenta, nie straciłem kontaktu z archeologią. W realiach życia w armii udało mi się przygotować moją pracę magisterską do publikacji. Nie było to łatwe, gdyż może poza jedną rozmową w czasie przepustki, odbywało się drogą korespondencyjną. Po powrocie z wojska, zajęty życiem rodzinnym i dydaktyką na 

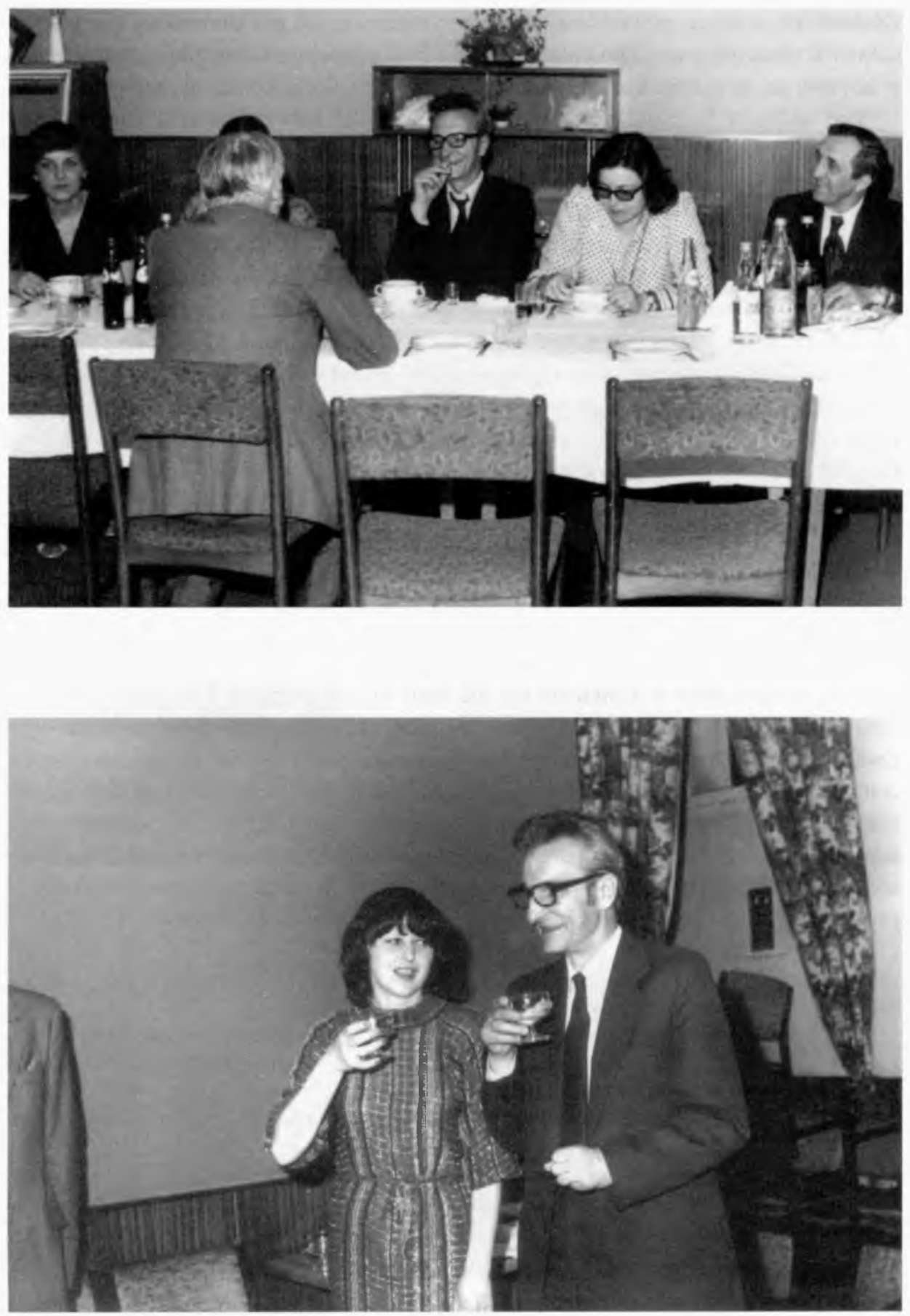

Doc. dr hab. Kazimierz Siuchniński na balu absolutoryjnym (1979 r.) 
toruńskim uniwersytecie, miałem niewiele okazji do kontaktów z Mistrzem; zaledwie jedna moja krótka wizyta w Poznaniu i kilka rozmów telefonicznych. Razem snuliśmy plany na przyszłość, także i te, dotyczące tematyki i realizacji mojego doktoratu. Nagła śmierć doc. Siuchnińskiego plany te zburzyła.

Niespodziewana i szokująca informacja o śmierci Mistrza - doc. dr. hab. Kazimierza Siuchnińskiego - pograżyła mnie w smutku i gniewie. Smutek spowodowało nagłe odejście Mistrza i życzliwego Przyjaciela. Gniew? No cóż - po odbyciu służby wojskowej, w początku 1981 r. stałem u progu własnej kariery i pomoc Mistrza była mi niezmiernie potrzebna, a On mnie osierocił. Przez 25 lat poczucie smutku i pustki mnie nie opuściło. Gniew szybko zastąpiłem postanowieniem, by zostać wiernym naukom Mistrza i naśladować Jego stosunek do archeologii, archeologów, studentów czy w ogóle do ludzi, do siebie także. Nie wiem, w jakim stopniu mi się to udało. Przyznaję, że przez te lata brakowało mi tak ongiś inspirujących rozmów i życzliwych uwag. Wielokrotnie zadawałem sobie retoryczne niestety pytanie, co Kaziu (tak nieoficjalnie nazywaliśmy Go w gronie studentów) powiedziałby o moim życiu i mojej archeologii. Mam nadzieję, że Mistrza nie zawiodłem. 